\title{
The Impact of Holistic Midwifery Care in Postpartum Anemia to Baby Growth (A Case Study in Ledug, Banyumas, Indonesia 2019)
}

\author{
Susilo Rini \\ Department of Midwifery \\ Harapan Bangsa University \\ Purwokerto, Indonesia \\ susilorini385@yahoo.com
}

\author{
Feti Kumala Dewi \\ Department of Midwifery \\ Harapan Bangsa University \\ Purwokerto, Indonesia \\ vettykumala@gmail.com
}

\begin{abstract}
Background: Comprehensive care during the puerperium is needed because this period is a critical period for both mother and baby. The prevalence of anemia in postpartum mothers according to WHO, amounted to $41.8 \%$ while in Indonesia the incidence of anemia was relatively high at $63.5 \%$. The incidence of anemia in postpartum mothers will not have an impact on the nutritional status of the breastfed babies, and can be a factor in stunting cases. Preliminary studies in Ledug Village, Banyumas Regency, January-April 2018 period showed that in addition to the incidence of 3 infant deaths and low birth weight infants, a high incidence of postnatal maternal anemia was still found, reaching $60 \%$. The aim: purpose of this study was to study and understand holistic care midwifery care for postpartum mothers with anemia. Method: This qualitative research used a descriptive observational method with a case study approach. The case study subjects were 1 anemic puerperal woman in ledug village, Banyumas regency, Central Java. The data collected through in-depth interviews, direct observation, and document study. Data analysis was performed descriptively based on 7 steps of Varney and SOAP. The results showed that postpartum mothers with anemia who had a history of anemia during pregnancy (HB 10.2 grams / $\mathrm{dL}$ ) gave birth to babies with low birth weight, and although mothers breastfeed their babies exclusively for 2 weeks but the baby's weight gain was only 300 grams and height is the same as at birth, which means less than normal. After getting postnatal nutrition counselling and regular postpartum visits by the midwife, on the 4th postpartum visit it is known that maternal $\mathrm{HB}$ increases to $\mathbf{1 1 . 7}$ grams / dl or the mother no longer suffers from anemia as the baby's weight rises according to her age which is up to 800 grams / month. Conclusion: So that proper comprehensive obstetric care for postpartum mothers with anemia was able to improve their condition which had an impact on improving the weight gain of the breastfed babies.
\end{abstract}

Keywords: postpartum, anemia, baby's weight

\section{INTRODUCTION}

Comprehensive care during the puerperium is needed because this period is a critical period for both mother and baby. The puerperium is a critical period for both mothers, where uterine implements return to their pre-pregnancy state. At this time the mother underwent many physiological changes, but on the other hand the mother must not only focus on self-care alone, but also on the care of her baby including breastfeeding.
Breastfeeding is a scientific process. Nutritional intake in nursing mothers greatly influences the quality of the milk it produces. Lack of nutritional intake can cause anemia. The incidence of anemia in nursing mothers will reduce milk production, both in quality and quantity

The prevalence of anemia in postpartum mothers according to $\mathrm{WHO}$, amounted to $41.8 \%$ while in Indonesia the incidence of anemia was relatively high at $63.5 \%$. Household Health Survey data (SKRT) in 2012 stated that the prevalence of anemia in postpartum mothers reached 45.1\% (Ministry of Health Republic of Indonesia, 2013). The rate of anemia in Central Java in 2012 reached 57.1\%, while in Banyumas Regency especially the Kembaran 2 Health Center in March 2019 postpartum mothers with Anemia were still quite high, reaching $60.57 \%$.

The occurrence of anemia in postpartum mothers not only affects the nutritional status of the mother itself but also on the nutritional status of the baby she is breastfeeding, and can be a contributing factor to cases of stunting. However, research conducted by Setyani (2018) shows that there is no significant relationship between nursing mothers with anemia and the nutritional status of infants.

Based on the Nutrition report in the First 1000 Days State of the World's Mothers in 2012 stated that the incidence of stunting is influenced by conditions in 1000 days of life, starting from the fetus in the stomach or when a woman is pregnant until the child is 2 years old and this period is called the windows critical period, because during this period there is brain development or intelligence and rapid body growth (Imtihanatun, 2014).

The results of a preliminary study in the village of Ledug found various problems that affected the high morbidity and mortality rates of mothers and babies during the puerperium. In 2017 exclusive breastfeeding coverage is only 68. During the period of January-April 2018 there were 3 Infant Mortality Rates. In addition to the high incidence of postpartum maternal anemia which reaches $60 \%$ the incidence of underweight babies is also still found. Therefore, further research is needed to regard the positive impact of the holistic midwifery care in postpartum Anemia to baby growth in Ledug Village in 2019.

\section{METHOD}

The research model is qualitative research used a descriptive observational method using case studies. The 
population was all postpartum mothers in the village of Ledug totaling 41 people, but the case study subjects were 1 postpartum mother with anemia on exclusive

breastfeeding in ledug village, Banyumas Regency, Central Java. The instrument for hemoglobin levels was the Cyanmethemoglobin method, while the heavy babies with age-appropriate scales.

The data were collect by in-depth interviews, direct observation, and document study. The procesing of Data Collect are divide into 4 step, there are:

1. Choose the postpartum mother whose doing exclusive breast feeding.

2. Doing in-depth interview not only with mother but also crosscheck by her family

\section{Direct observation consistently}

4. Crosscheck with the document study of postpartum mothers.

For the last the data was analysed by performed descriptively based on 7 steps of Varney and SOAP.

\section{RESULTS AND DISCUSSION}

The results showed that the respondent named Ny. P is 34 years old giving birth a second time and has never had a miscarriage. The distance of the first delivery to the last is 17 years. Mother's gestational age 39 weeks, the birthplace in the Puskesmas, result no complications for the mother, spontaneous complete birth placenta, no laceration of the birth canal, the amount of bleeding at the third stage is $150 \mathrm{cc}$ and the fourth stage is $65 \mathrm{cc}$, the length of labor at the first time is 6 hours 15 minutes, 2 nd stage 5 minutes 3rd stage 5 minutes and IV stage 2 hours, female baby sex, PB $47 \mathrm{~cm}$ good baby condition, BB 2450 grams, assisted by midwives. Weighing results at 2 weeks of age showed that the height of baby is $47 \mathrm{~cm}$ and her weight is 2750 grams. Whereas at the age of 1 month the babies had weight reached 3250 grams.

"... my first child is 17 years old, this is the second child, a girl born in a midwife, $47 \mathrm{~cm}$ long, but weighs only 2450 grams, said midwifery, I was told to eat nutritiously, not to be challenged, to take medicine, last yesterday weighed 3250 grams at health clinic .. "

The results of the study found that the pattern of nutrition during pregnancy Mothers eat 3 times a day serving 1 plate of vegetable side dishes, but sometimes mothers also consume instant noodles 2-3 times a week. at present, starting from the first day of postpartum to 2 weeks of assessment. Mother said after giving birth she ate 3 times a day, serving 1 plate, the composition of rice, vegetables, side dishes and fruit. Drink 7-8 glasses / day type of water and sweet tea. Mothers have no complaints about eating patterns but almost never consume blood-added tablets from the midwife because of discomfort.

"... eat it 3 times a day, use rice, vegetables, side dishes ... but sometimes I also eat noodles but don't often arround 2-3 times a week ..."
"... medicine from midwifery, which is red, sometimes taken sometimes not because it feels bad, makes nausea, there are still 2 packs ..."

Infant weight is the indicator most often used to assess the nutritional status of infants, which is the result of meeting their nutritional intake needs through exclusive breastfeeding. Soetjiningsih (2012) states that the increase in weight is calculated based on the table increase in weight, with a benchmark ideal infant weight gain in the first year, namely: 700-1000 grams / month in the first quarter. Research has proven that the nutritional status of pregnant and lactating women affects the baby's weight. This is consistent with the 2012 SKRT data which states that the prevalence of puerperal women with anemia is around $45.1 \%$ of all pregnant women in Indonesia. This will affect the expenditure and quality of the milk it has.

Anemia in the puerperium is a condition of maternal $\mathrm{Hb}$ levels below the normal limit during the puerperium (Prawirohardjo, 2014). The level of normal postpartum maternal $\mathrm{Hb}$ is $11 \mathrm{gr} \%$ (Manuaba, 2010). Postpartum mothers who have anemia have hemoglobin levels of less than $11 \mathrm{gr} \%$ (Bothamley, 2011)

The incidence of anemia in postpartum mothers can be caused due to lack of nutritional intake, in women who have anemia can cause risks for both mother and fetus. This is supported by the theory of Notobroto (2003) that poor nutrition can cause anemia and pregnant women with anemia can increase the risk of maternal death, prematurity, Low Birth Weight Babies (LBW) and infant mortality rates. The cause of iron deficiency anemia problem indirectly is the lack of people's purchasing power to consume food sources of iron, especially with high biological readiness coupled with female blood loss through menstruation or in labor.

Anemia is most often caused by iron deficiency and most of the iron bound in hemoglobin which functions specifically to transport oxygen for metabolic purposes in the tissues. Thus, if the mother is anemic, the metabolism in the tissue will be disrupted thereby reducing the quality of breast milk. This is consistent with the results of research Alvira, et al (2018), at the Tegalrejo Public Health Center showed that there was a significant relationship between the incidence of anemia with postpartum mother's milk production

The results of in-depth interviews at Ny.P Age 34 Years, showed that mothers in a healthy reproductive age so that according to the vulnerable or small age the risk of bleeding occurs in the puerperium, but with a gestational distance of 17 years, showing the distance of labor that is too long more than 5 years. This is often associated with the risk of high blood pressure and excess protein in the urine after 20 weeks of pregnancy (preeclampsia), bleeding during labor, premature birth, low birth weight of the baby. pregnancy affects the capacity of the uterus to accommodate the needs and growth of the fetus. Distances between births that are too far away make this physiological advantage disappear (Manuaba, 2007).

Although there was no bleeding, the mother suffered from anemia. This has an impact on the state of the baby who has both PB $47 \mathrm{~cm}$, and BB 2450 grams, ie babies born with low birth weight. If the pregnant woman is fulfilled her nutritional needs (energy, protein, vitamins, minerals and fluids) then she 
can undergo pregnancy well and safely, and the baby is born physically and mentally healthy. Foods consumed during pregnancy can form more non-fat body tissue (Wibisono and Dewi, 2009).

Babies experiencing LBW (Low Birth Weight), that is, BB babies 2450 grams, this condition can be caused by several things such as the nutritional pattern of the mother during pregnancy which is $1 / 2$ portion at every meal and the habit of consuming unhealthy foods such as instant noodles which is quite frequent ie 2-3 times a week. Strengthened by the habit of not consuming blood-added tablets from midwives because of discomfort. Intake of added blood tablets during pregnancy of at least 90 tablets is also very important to meet the nutritional needs of the mother that supports fetal growth and development. If the intake of nutrients is insufficient it can cause health problems in the mother and baby. Disorders in infants include the process of growth and development of children, infants prone to illness, susceptible to infection (Rini, S and Dewi, F.K, 2016)

The laboratory tests also show that hemoglobin levels in Ny.P are only $10.2 \mathrm{~g} / \mathrm{dl}$. This is included in the category of mild anemia. The situation of mild anemia has no visible symptoms but in the long run it will have an effect on severe anemia and will gradually reduce the nutritional status of the baby until the age of 2 years while the baby is still breastfed. However, after a comprehensive midwifery care was performed, and the mother was given vitamin A therapy 2xi, Fe tablets $1 \mathrm{x} 1 /$ day. The mother's condition improved with HB levels of 11.7 grams / dL. Postpartum mothers are required to take 200,000 IU of vitamin A supplements, 1 capsule taken immediately after delivery and 1 capsule taken 24 hours later. Consumption of iron tablets for 40 days postpartum (Ministry of Health Republic of Indonesia, 2015) is done to overcome and prevent postpartum anemia.

Anemia in puerperal women can be interpreted as a condition where the level of hemoglobin (HB) in the mother's blood is lower than the normal value through laboratory tests. The HB category is said to be Normal if more than $12 \mathrm{mg} /$ $\mathrm{dL}$ and is said to be anemic if it is less than $12 \mathrm{mg} / \mathrm{dL}$ (Setiyani, 2013). The prevalence of anemia in breastfeeding mothers can be influenced by several things such as the intake of postpartum mothers, and noncompliance with taking blood-added tablets, during pregnancy and post-partum, the absence of government programs related to supplementation of blood-added tablets in the first 6 months of birth (breastfeeding) can also be a

reinforcing factor anemia in postpartum mothers. This condition greatly affects the nutritional status of infants, which is characterized by weight gain in infants.

The nutritional status of a baby is defined as the balance of nutrients the body needs by using the body weight indicator per age $(\mathrm{BB} / \mathrm{U})$, which is then matched with the baby's weight gain table according to sex.

Breast milk is the main food for infants aged 0-6 months based on the increase in body weight because it is given without any additional food or drinks other than drugs. However, infants aged 0-6 months are prone to disease, mismatched frequency and duration in breastfeeding will also have an impact on increasing morbidity in infants so that it also affects the nutritional status of infants.

In this study there were 7 babies with less weight gain in which 4 of them received exclusive breastfeeding from postpartum Anemia mothers. The results also showed that proper midwifery care can improve the health conditions of nursing mothers that have an impact on improving the health conditions of the breastfed babies. This is because the mother's health condition will affect the quality of the milk produced by her, so that it will affect the health of the baby she is breastfeeding too. This study is in line with research conducted by Nadilla and Soimah (2018) at the Tegalrejo Public Health Center in Yogyakarta which states that of 28 postpartum anemia mothers, only 3 people have good milk production, while 22 others.

\section{CONCLUSION}

Comprehensive midwifery care for postpartum mothers with anemia can improve maternal health status which has an impact on the weight gain of the babies they feed.

\section{SUGGESTION}

Midwives should provide comprehensive care for postpartum mothers in accordance with the counseling and management needs of postpartum visitation program policies (minimum 4x). Postpartum mothers should consume bloodadded tablets during breastfeeding and receive nutritional care that is nutritious so as not to suffer from anemia, and provide an environment with good PHBS. Policy holders should make policies related to blood tablet consumption program during childbirth to overcome the incidence of anemia in breastfeeding.

\section{REFERENCES}

[1] Kementerian Kesehatan RI. Direktorat Jenderal Bina Gizi dan Kesehatan Ibu dan Anak. Petunjuk Surveilans Gizi. Jakarta. 2012

[2] Ikatan Dokter Anak Indonesia. Nutrisi Pediatrik dan Penyakit Metabolik. Jilid I. Jakarta: Badan penerbid IDAI. 2011.

[3] Riset Kesehatan Dasar.Jakarta : Badan Penelitian Kesehatan Kementrian Kesehatan RI.2010.

[4] Subramanian, S.V, K. Ackerson, leland ScD, Davey Smith George, MD, DSc, dkk. Association of Maternal Height With Child Mortality, Antropometric Failure, and Anemia in India. Journal American Medical Association. 2009; 301 (16): 1691-1701.

[5] Shashi raj, Faridi MMA, Usha Rusia, dkk. A Prospective Study of Iron Status in Exclusively Breastfed Term Infants Up to 6 Month of Age. International Breastfeeding Journal 2008, 3:3.

[6] Setiyani, L. Hubungan Kejadian Anemia Pada Ibu Menyusui dengan Status Gizi Bayi Usia 0-6 Bulan. skripsi.Semarang :Badan Penerbit Universitas Diponegoro. 2013.

[7] Mahan, L.Kathleen and Stump, Sylvia Escott.. Krause's Food \& The Nutrition Care Process. Edisi 13. Philadelpia : WB Saunders Co. 2012.p 731- 738

[8] Ari Sulistyawati. 2009. Buku Ajar Asuhan Kebidanan Nifas. Jakarta:Andi offset

[9] Bahiyatun. 2009. Buku Ajar : Asuhan Kebidanan Nifas Normal Jakarta

[10] Eny Ratna A, dkk. 2009. Asuhan Kebidanan Nifas, Jogjakarta:Mitra Cendikia Press

[11] Jannah, N. (2011). Asuhan Kebidanan Nifas. Yogyakarta:Ar-Ruzz.

[12] Julianti, S.Kep, dkk .2014. Materi Pelatihan Postnatal Care. Universitas Indonesia.

[13] Keluarga Berencana untuk Pendidikan Bidan. Jakarta : EGC.

[14] Kurniawati, T., Chabibah, U. (2014). Pelaksanaan Pendidikan Kesehatan Tentang Ambulasi Dini Ibu Post Partum. Jurnal Kebidanan dan Keperawatan Vol. 10 hal 54-63

[15] Lestari, EP. (2010). Hubungan Rawat Gabung Dengan Mobilisasi Dini Pada Ibu Nifas Hari Pertama di BPS Endang Desa Banaran Kabupaten Kandangan Kabupaten Kediri. Jurnal AKP No 2 Obstetri Fisiologi. Bagian Obstetri Gynekologi FK UGM. 
[16] Rini,S dan Dewi, FK. 2016. Panduan Asuhan Nifas dan Evidence Based Practice. Yogyakarta: Deepublish

[17] Setiyani, L dan Kusumastuti, AC. 2013. Hubungan Kejadian Anemia pada Ibu Menyusui dengan Status Gizi Bayi Usia 0-6 Bulan. Journal of Nutrition College. Di unduh dari http://ejournalsl.undip.ac.id/index.php.jnc pada 02 Juli 2019 